This is an electronic reprint of the original article. This reprint may differ from the original in pagination and typographic detail.

Author(s): Honkasilta, Juho

Title: "Diagnosing" the Need or in "Need" of a Diagnosis? Reconceptualizing Educational Need

Year: $\quad 2017$

Version:

Please cite the original version:

Honkasilta, J. (2017). "Diagnosing" the Need or in "Need" of a Diagnosis?

Reconceptualizing Educational Need. In K. Scorgie, \& D. Sobsey (Eds.), Working with Families for Inclusive Education : Navigating Identity, Opportunity and Belonging (pp. 123-141). Emerald. International Perspectives on Inclusive Education, 10. https://doi.org/10.1108/S1479-363620170000010014

All material supplied via JYX is protected by copyright and other intellectual property rights, and duplication or sale of all or part of any of the repository collections is not permitted, except that material may be duplicated by you for your research use or educational purposes in electronic or print form. You must obtain permission for any other use. Electronic or print copies may not be offered, whether for sale or otherwise to anyone who is not an authorised user. 


\title{
“DIAGNOSING” THE NEED OR IN “NEED” OF A DIAGNOSIS? RECONCEPTUALIZING EDUCATIONAL NEED
}

\author{
Juho Honkasilta
}

\begin{abstract}
This chapter is based on compulsory school experiences of students diagnosed with Attention Deficit Hyperactivity Disorder (ADHD) and their parents in the educational context of Finland. Located in the theoretical framework of Disability Studies, the chapter aims to contribute to theory of inclusive education by initiating a new dialogue on conceptual foundations of inclusive schooling. In this regard, the chapter first deconstructs the concept of educational need that stems from the field of traditional special education as contradictory to the original ideals of inclusive education. It then moves on to reconstruct the concept of educational need in accordance with the foundational values of inclusion, that is celebration of human diversity and resistance to dichotomies of ab-/normality and dis-/ability and proposes an approach for future implementation of inclusive education.
\end{abstract}

Keywords: ADHD, disability studies, inclusive schooling, ab/normality, dis/ability, discourse 
A regular morning. I wake up to the alarm clock ringing. I shut it down and fall back asleep. I wake up to someone shouting. My mother is in the doorway, scolding. I'm late again. I throw my backpack over my shoulder and leave for school. It's an immensely sad feeling; what's the point in all this. How did we get here?

Confusion, blame, warnings. It's hard to remember the happy moments. I know they existed - they had to - I just don't remember. I hear I was wild as a kid. Cheerful, active, happy maybe, but wild. You would think they could have brought me to a different kind of understanding of myself. Why exactly was that label chosen to describe my qualities and define who I am? It wasn't the only label I got; over the years I've also learned to understand myself as stupid, lazy, mean, listless, argumentative, undisciplined, and badly motivated. My folks came to school for meetings all the time. I remember often thinking to myself what the $f^{* * * *}$ was wrong; it seemed that all the adults were shouting all the time. I know they meant well - of course they had to - I just didn't believe them. It didn't come through.

A pill and a label. My breakfast now came with a pill. The adults around me seemed hopeful, even relieved: my parents and teachers were smiling again, and fewer school meetings were set up. The pill started to define the quality of my daily life. And I started to be defined by the letter combination ADHD. It was weird. Partitions appeared at school. I was isolated from peers who had once been friends, but it was argued my motivation had increased. I learned that even if I was wild and lazy, it wasn't my fault, even if the fault was in me. I was at the same time ill and normal. I was bullied and seen as a bully. I pulled away. It seems they don't listen to me; never really hear me. Well, it'll be OK; junior high is over soon and my whole life is ahead... As long as I learn to ask that I'd be listened to and supported in things that are important to me. As long as I learn to forgive - adults, peers, myself. But what if nothing changes... 
The above imaginary, provocative story of a young person's life trajectory serves several functions. First, it illustrates a master narrative of Attention Deficit Hyperactivity Disorder (ADHD), a neurodevelopmental (American Psychiatric Association, 2013) or behavioral and emotional (World Health Organization, 1993) disorder characterized by impairing behavioral features, such as distractibility, restlessness, and impulsiveness. This master narrative also explains the higher risks of social exclusion among children whose selfcontrol and/or interaction skills do not meet the expectations of a social environment. It suggests a mindset that maintains that a child's deviant behavior is rooted mainly in natural or biological causes, independent of the value-laden cultural and social practices embedded in the environment in which the child functions. Thus, diagnosed children "suffer" from a neurodevelopmental condition owing to which they are at risk of developing adverse life trajectories, such as lack of school completion, unemployment, relational difficulties, or substance abuse, if the condition is not identified and adequately treated early on.

Secondly, the scenario reflects varying discourses present in my interview research on ADHD conducted with 18 mothers of children diagnosed with ADHD and 13 diagnosed youth (aged 11-16 years) in their narratives regarding school going in Finland, upon which this paper premises (Honkasilta, 2016). Finally, the account suggests a representation of inclusive education that is situated in a psycho-medical discourse emphasizing need and directed by the language of special education, which is commonly integrated into the daily activities of homes and schools. In this regard, the narrative resonates with Adam's (2010) notion that “'inclusion' has become more concerned with identifying and containing need than in meeting it" (p. 77).

In this chapter, by adhering to the theoretical framework of Disability Studies, I respond to Danforth and Naraian's (2015) call for initiating a new dialogue on conceptual foundations of inclusive schooling among educational scholars in order to generate a 
transnational theory of inclusive education. I first use ADHD as a platform to explore criticism regarding current conceptualizations of inclusive education which regard special education knowledge as a necessary bedrock for achieving the instructional and social goals of inclusive education. I further focus on deconstructing the concept of educational (special or remedial) need as contradictory to the original ideals of inclusive education, which focused on celebrating human diversity. Finally, I propose an approach to inclusive education for future implementation, by reconstructing the concept of educational need in accordance with the foundational values of inclusion, based in humanistic psychology. I argue that inclusive education cannot be fully achieved solely through directive or material changes related to pedagogical practices but, and fundamentally so, through a change in mindset manifested in everyday social and discursive practices shared by home and school.

\section{Maintaining the status quo: Current conceptualizations of educational need}

Meeting students' individual educational "special" needs has become an emergent trend in contemporary compulsory educational policy-making rhetoric and practice, especially in Western developed countries. In theory, this seems to live up to the foundational ideals of inclusive education. In reality, however, this depends on which of the many interpretative frames or discourses regarding inclusion and inclusive education one adheres to (Ainscow, Booth \& Dyson, 2006; Armstrong, Armstrong \& Spandagou, 2011; Dyson, 1999; Walton, 2015) and how practices deemed inclusive are perceived and experienced by the stakeholders in the first place (i.e., students, parents, school personnel). The core of inclusive education in its "broad" sense is to respond to learner diversity and the barriers experienced by learners, which are embedded in existing practices and ways of thinking (Ainscow, 2005, 2007; Ainscow et al., 2006). However, the contemporary enactment of inclusive education focuses on diversity of learning largely in terms of measurable academic process, progress, and performance (Armstrong et al., 2011). Based in the medical model of disability, this tends to 
mean that a diagnosis of a certain kind is followed by identification of distinctive pedagogical approaches tailored to specific "needs" associated with the impairment, disability, or disorder. Disability, therefore, is rooted in nature (e.g., genetics or neurobiology) and located within an individual. Across the years inclusion and need rhetoric have merged with traditional special education practice and rhetoric (e.g., Graham \& Slee, 2008; Miles \& Singal, 2010).

However, such rhetoric of inclusion does not by any means guarantee inclusive education, since the very concept and its realization into practice is fundamentally predisposed to exclusion (Armstrong et al., 2011; Graham, 2015; Graham \& Slee, 2008; Slee, 2013). Slee (2013) notes, that

[w] can tread the traditional special educational path and call it inclusion, but we will create more strangers, more surplus children and more exclusion. This means that we need to carefully examine proclamations of inclusive education. Many of those who describe themselves as inclusive educators are not looking for education or social reform to build engaging communities; they seek clients to practice on. (p. 906)

By exclusion I refer to both (1) social practice, such as the processes that deny the benefits of a particular classroom or school owing to the perceived attributes of the student, and (2) discourse practice, such as denying the establishment of a social operating environment that embraces human diversity and acceptance of others and self. As noted by Vehmas (2015), the debate surrounding inclusion is in essence an empirical dispute about the morally, politically and pedagogically good or bad outcomes of inclusive versus segregated arrangements. In this paper I opt out of this dispute regarding arrangements of inclusion that by nature may promote exclusion. Instead, I want to focus on prevailing discourses present in 
the current practice of inclusion that undermine inclusive education. I want to clarify at the outset that I am not out to trivialize special education per se. The domain of special education has contributed to the movement toward what Ainscow and colleagues (2006) term a "narrow" definition of inclusion by promoting the participation and learning of specific groups of student, such as students with certain impairments (i.e., absence of ability or lesser ability) or those labeled "gifted." It is however the discourses of norm and deficit, mainstream and special, adhered to and reproduced in the very grouping and labeling of students of "specific kinds" that simultaneously pose barriers to the broader perspectives of inclusive education by ignoring some of its quintessential values.

The inclusive education agenda originated to protest against the status quo of schooling that creates and maintains dichotomies such as mainstream-special, able-disabled, and fundamentally, normal-other. Situated in the social interpretation of disability ${ }^{1}$, it contrasts with traditional educational views that maintain disability as innate individual deficit (i.e., medical model) and disadvantage and exclude people deemed impaired (see, e.g., Armstrong et al., 2011; Thomas \& Loxley, 2007). In this light, it is argued that the present day conceptualization of "inclusion" paralleled with special education is a watered down feelgood rhetoric of educational policy-making that masks and protects the very status quo the inclusive education paradigm arose to oppose in the first place (Armstrong et al., 2011; Graham, 2015; Graham \& Slee, 2008; Slee, 2004) - it is "a strategic cover for traditional, deficit-based practices" (Naraian, 2013, p. 361).

There are two characteristics of discourse that guide further elaboration of above claim. First, discourse(s) "form the objects of which they speak" (Foucault, 1972, p. 49).

${ }^{1}$ Following Gabel (2009, p. 2), by using the concept "social interpretation" instead of "social model" of disability I refer to wide array of disability theories that regard disability as a social construct not solely owing to the way society is organized for persons with impairments (i.e., "hard" social model) but owing to everyday social and discursive practices that construct (and potentially de- and reconstruct) disabilities and impairments in various ways (e.g., identity constructions, embodiment). 
Pedagogical discourses based on the medical model of disability are pervasive throughout a child's schooling, as presented in the opening narrative. Indeed, explaining school behaviors, implementing pedagogies, and planning educational interventions, as well as involving parents in school, are built on the idea of an object of certain kind (e.g., "ADHD student") formed by psychomedical discourse (see Hjörne, 2006; Hjörne \& Säljö, 2014; Honkasilta, Vehkakoski \& Vehmas, 2015). However, when complex social and educational problems are reduced to a psychomedical deficit using the language of labels, disorder and dysfunction i.e., a child is "special," "normal," "gifted," "ADHD," "autistic," "disabled," etc. - one may internalize problems as solely based in the individual (Brady, 2005; Harwood, 2006). And, when internalization of deficit-based language and discourse becomes part of a child's worldview and self-perception, identity construction can be affected, as the child may perceive of him/herself as fundamentally flawed—a view that the use of diagnostic labels promotes (Brady, 2005; Honkasilta, Vehmas \& Vehkakoski, 2016).

The second characteristic of discourse that maintains the status quo is that agents have limited access to discourse(s) (van Dijk, 1996). Kittay (2006) suggests that the language of disorder and dysfunction creates a concept of the ideal in relation to which "those who inhabit the space of the non-normal" usually "occupy positions marked as not valued, not desirable, stigmatized" (p. 96). Thus, a child with a diagnosis of certain kind may not have access to discourse(s) that would view him/her as "normal kind" in a classroom setting, because his/her actions, performance, traits, or mere labels contradict the normative ideal unless of course, classroom practices employ such discourse(s) that embrace affinity and acceptance of all, therefore reconstructing the prevailing norm. Thus, the uncritical employment and reproduction of discourses of certain kind both segregate "disordered self" from "valued self," and "other" from "norm." 
To conclude, as long as the identification of educational need is foregrounded in the differentiation of particular student characteristics, skills, capacities and weaknesses, the very practice claimed inclusion goes against the foundational values of inclusive education which focused on embracing diversity and denaturalizing "normality" (Graham \& Slee, 2008; Tait, 2010). The question those practicing inclusion ought to ask in light of this becomes: what are the types of identities-i.e., being recognized as a certain "kind of" person in authentic interactional and contextual situations (Gee, 2000-2001) — made available to those labeled as having educational need?

\section{Recognition: Creating educational need via labeling}

\section{Deconstructing the concept of educational need}

Being recognized or identified as "certain kind" utilizing the medical model of disability heavy influences the rhetoric and practice of identifying and catering for individual educational needs in both school and home environments. In many countries, such as Canada, Australia, and the USA, catering for educational need relies on what Itkonen and Jahnukainen (2010) term in their comparative analysis a disability model (commonly referred to as the diagnostic-prescriptive model), in that special need intervention is diagnosis driven (also, Graham \& Jahnukainen, 2011; Itkonen \& Jahnukainen, 2007). This educational policy shapes and reflects teacher and parent practices accordingly. Especially in the case of the so-called "special needs" of students being deemed emotionally and/or behaviorally disordered, discourses among educators are likely to draw on psychomedical conventions that account for school failure by citing a deficit in brain functioning (Bailey, 2014; Hjörne \& Säljö, 2014). Not surprisingly, receiving recognition and support for their child at school is one of the reasons families seek diagnosis for their child in the first place (Emerald \& Carpenter, 2010; Honkasilta et al., 2015). 
In the Foucauldian sense, the ethos of recognizing educational (special or remedial) need authorizes the power of governance toward maintaining an ideal of "normality" (Tait, 2010). Since those who do not fit into the normative frame are at risk of becoming labeled according to moral judgments - i.e., the student is lazy or malicious - therapeutic and psychomedical approaches have been harnessed as a counter-discourse to protect students from such judgments - i.e., the student has ADHD. Diagnostic labels, therefore, serve as a legitimate account for deviancy, since they normalize the perceived anomaly by asserting that the student "suffers" academic and social consequences owing to compulsive biological, neurological, and/or psychological conditions. The other side of the coin is that when a school promotes student diagnoses to identify and nurture a "need," professionals can simultaneously distance themselves from the responsibility of adequately meeting that need, since the diagnosis per se is legitimate medical proof that the problem lays within the child, not the social environment and its everyday practices over which they hold influence (Adams, 2008; Bailey, 2014; Brunila, 2012; Vehmas, 2010). This claim is supported by a recent study suggesting that principals from eight European countries, including Finland, regard students' school failure to child and family factors (Rinne, Järvinen, Tikkanen, \& Aro, 2012). This is a globally held view among school personnel (Kulinna, 2007-2008). Thus, sustaining the medical model of disability facilitates the maintenance of school institutions' sanctity by placing the blame for social and academic failure on the child and his/her family. In the same way, family adherence to the medical model of disability functions as absolution from the blame of not meeting the sociocultural criterion of "good parenting" (Bailey, 2014; Honkasilta, 2016; Honkasilta et al., 2015; Singh, 2004).

So, at worst, need, as it is currently conceptualized and executed in practice is nothing but a way of reconstructing blame, and as such, is counterproductive. The current rhetoric regarding educational, remedial, or special need constructs a reality in which the one in need 
deviates from those who are not, since the very sense of need is constructed in relation to ideas of "normal development," "normal behavior," "normal cognitive functioning," "normal performance," "normal home life" and so on and so forth (Tait, 2010; Vehmas, 2010). Thus, the focus is less on individual need, but rather on cultural and institutional needs. In short, there is a cultural need for a theory and practice stemming from the medical model of disability that leads to an internalization of the idea that societal and social problems, such as behavioral difficulties at school or school failure, are in fact individual based. Psychiatric diagnoses, thus, function as a gateway for navigating social institutions and everyday interactions to negotiate a means of societal support and recognition of "certain kind." In addition, current conceptualizations of need imply the employment of different strategies to achieve certain imposed academic or behavioral learning goals, for the purpose of attaining valued skills and performance, which are socially validated. Brunila (2012), in her study of the effects of therapeutic interventions in project-based educational practices dealing with young adults who were on the margins of society in Finland, aptly concluded that "the focus of therapeutic intervention seems to be on working towards an ideal individual who is flexible in accordance with the needs of the economy" (p. 460). Therefore, what is construed as individual need is in actuality institutional need; need that is constructed through the apparatuses of socialization.

\section{Education policy in Finland: An inclusive perspective on education}

Finland counters the prevailing utilization of the disability model of educational need. Instead, the assessment of remedial or special education provision in Finland is made based on observed individual educational need(s) and behavioural characteristics defined within schools according to a multi professional evaluation, in which the views of teachers, special needs teachers, and caretakers are regarded (Graham \& Jahnukainen, 2011; Itkonen \& Jahnukainen, 2007; 2010; Jahnukainen, 2010). For instance, Björn and colleagues (2016) 
compared the policies of the response to intervention (RTI) framework of the United States with those of Finland in the context of implementing special education services. They conclude that with similarities between the policies as regards the three-tier framework of providing early support for all students, in the USA RTI is primarily related to the renewal of diagnostic procedures (e.g., identifying specific learning disabilities, emotional or behavioral disabilities, etc.) and noted that special education services were not assumed in the first two tiers. In Finland, on the contrary, formal diagnoses of impairments, disabilities, or disorders are not needed for receiving special education services in compulsory schooling. Instead, services are provided for all students from the onset of support need in each of the three tiers; for example, as individualized instructions or part-time special education services.

Finland, thus, provides an auspicious study context for examining the prospects and challenges of inclusive education from the viewpoint of families of so called "special needs" children, since, in respect of school policy, diagnoses such as ADHD are not predetermined as a defining characteristic of pedagogical decision making or of a student's school path. This emphasizes the role of social and discourse practice in the formation of individual school trajectories.

Families on the school path: Labeling "need" as a strategy for recognition

Although the enactment of remedial or special education, or pedagogical practices in general, in Finland are not bound to disabilities or disorders legitimized by diagnoses, diagnosing a child with ADHD was sought by mothers as a response to ongoing troubling feedback from educators regarding a child's school behavior and performance to avoid blame. Additionally, diagnosis was perceived as a school-driven necessity by mothers. Parents' lack of confidence in teachers' knowledge of ADHD and ability to support their children's psychosocial well-being at school often left them with no choice but to medicalize 
and pathologize human differences. Thus, the psycho-medical understanding of their child's behavior was expected to promote the match between the child and school, serving as a mediator between parents and teachers (see, Honkasilta, Vehkakoski \& Vehmas, 2015).

In this way, the ADHD label was laden with a promise of recognition (Honkasilta, 2016). It was expected to (1) explain a child's behavior and performance and thus reframe blame, (2) establish a setting for more a constructive approach to collaboratively supporting the child's schooling, (3) entitle the child for adequate remedial or special education services and accommodations, and (4) humanize the child in terms of meeting the child with empathy and in protecting his/her identity from being constructed upon non-valued traits at school, such as being lazy or unruly. It was also expected to (5) empower mothers to negotiate their agency, expertise, and identity in the realm of their child's schooling and thus, to become involved. Being a mother of a so-called "ADHD child" with "special needs" was constructed as a "project of parenting according to medically conceived truths of behavioural disorder" (Bailey, 2014, p. 99), though according to Finnish education policy, there are no educational grounds for parents to reproduce the medical model of disability.

Interestingly, and contrary to their mothers, children diagnosed with ADHD did not place as much hope on psychomedical explanations in terms of understanding their school experiences and who they are. Although having also adopted and learned to utilize the discourse employed by their mothers of ADHD as a medical entity which frees one from moral responsibility, ADHD was also internalized a morally questionable form of "otherness" that was to be controlled and contained, as well as an imposed social stigma which entailed norm expectations the children had difficulty relating to (Honkasilta, Vehmas \& Vehkakoski, 2016). As regards unwanted classroom behavior, the youth stressed social and interactional determinants and the teacher's role in its manifestation and escalation, rather than referring to 
predetermined and straightforward moral assumptions about ADHD symptoms (Honkasilta, Vehkakoski \& Vehmas, 2016).

Thus there are limitations to the medical model of disability. Such an approach can be humanizing in that it provides informed knowledge of the disorder and subsequent psychomedical understanding and means to enhance interactions, relationships, and learning. However, treating behaviors as symptomatic can also be dehumanizing, as it may prevent stakeholders (i.e., the child, family members, and teachers) and the social environment (home or school) from examining the nature of relationships and interactions, or other factors that may cause or provoke the unwanted behavior in the first place. For instance, if a student acknowledges his/her non-compliance with teacher's expectations as a justified reaction of frustration or anger due to experienced neglect of his/her needs for respect or trust (Honkasilta, Vehkakoski \& Vehmas, 2016), whereas the teacher regards so-called 'misbehavior' as a manifestation of a psychiatric disorder, approaches to adequate intervention are problematized from the beginning. One may thus overlook the importance of listening to children and young people as a means to promote inclusive education (Walton, 2015). Furthermore, the goal of promoting empathy through psycho-pathologization sought by mothers imposes identity challenges for those "in need" since it is oversimplifying and insufficient in making sense of the experiences and meaning-making of youth. But even more importantly, it does not regard the foundational needs of all students, such as the need to be heard, respected, and accepted by oneself and others.

\section{Reconstructing the concept of educational need: Universal need discourse}

As Vehmas (2010) notes, defining something as a "special need" in educational practices is not based on empirical fact or objectivity, but "a matter of making normative value judgements of what is good and valuable for pupils, and people in general" (p. 91). To 
this effect, I propose a way to conceptualize need in educational practice that is devoid of value-laden normative judgments.

In his discussion of how to address challenging behavior, Glasser (1996; 1997) emphasized that an individual is willing to comply if his basic needs for belonging, power, freedom, and fun are satisfied. The premise of Glasser's Choice Theory is that changes in behavior must be made freely and volitionally, not as a result of rewards, threats, or punishments, which are externally imposed. Similarly, self-determination theory (SDT) (Deci \& Ryan, 2000; Ryan \& Deci, 2000) focuses on the examination of contextual social structures that either facilitate or impede self-motivation. Self-determination theory emphasizes the interrelatedness of one's innate psychological needs for competence, autonomy, and relatedness, and human motivation. According to these theories, there is a clear difference between learning as an institutional objective imposed by others (e.g., teachers and parents) and demanded of the student, and learning as an endogenous need toward which an individual directs his actions. My conceptualization of need is derived from a communication process called nonviolent communication (NVC) established by Marshall Rosenberg (2003), which emphasizes the importance of everyday social interaction in meeting needs. Although not a theory of motivation but an empathic interaction, NVC shares similarities with the aforementioned humanistic approaches by accentuating the importance of freedom of choice as a premise for willingness to comply with the requests of others, and by considering needs as a universal force underlying all human action. NVC does not approach needs by limiting them to the somewhat hierarchical categorization of basic needs, but rather applies a broad vocabulary of varying situational needs.

I find the focus of NVC on face-to-face interaction applicable here for two reasons. First, it provides theoretical tools for furthering discussion regarding the concept and practice of educational (special or remedial) need outside the conceptualization and practices of 
deviance identification and/or labeling. Second, it strongly resonates with one of the priorities of inclusive education conceptualized by Danforth and Naraian (2015). They introduce communicating values of inclusive education in caring interpersonal relationships as a foundation stone of inclusive education by citing Nel Noddings' (1992) contention that the main aim of education "should be encouraging the growth of competent, caring, loving and lovable people" (p. 10, in Danforth \& Naraian, 2015, p. 76), not living up to the expectations of neoliberal education policy characterized with standardized testing and urge on competing. Noddings provides two concepts that guide teachers towards ethic of caring in interaction with their students: engrossment, which refers to completely offering oneself to the needs of another without qualifications, and motivational displacement, which describes the way teachers put aside personal motivations, concerns and goals and focus instead on the purposes and needs of the student (Noddings, 1984; 1992, in Danforth \& Naraian, 2015, pp. 76-78). As I will further demonstrate, NVC approach to understand interpersonal interaction as contextual manifestation of needs 'alive' within each one of us provides practical means to communicate these values of inclusive education.

The medical model of educational need and traditional special education rhetoric have enabled educators to see beyond manifest student conduct through the lens of the medical model of disability - e.g., a student talks back at the teacher because of impulsivity, a characteristic of ADHD. This educational need ethos, however, disregards the student's basic human needs in the context of everyday interactions and authorizes experts such as (special education) teachers and psychologists to possess power over students' (and parents') voice and agency in determining what constitutes "need." This reliance on expert knowledge is misleading, since students who have ADHD, or some other diagnosis, share the same human needs as other students, school personnel, and parents; such as the need for affinity, friendship, security, acceptance, trust, joy, happiness, support, learning, help, respect, 
recognition, and being heard. Therefore, regarding an unwanted behavior such as talking back at the teacher as a manifestation of an unmet situational need, such as a need for more respectful interaction with the teacher, rather than a manifestation of individual psychopathology, provides a more constructive here-and-now approach to catering for student needs, and a basis for social and discourse practices that is in accordance with the inclusive education premise of meeting learner diversity. Yet, all stakeholders have needs, which also must be considered and respected. Let me elaborate this further with an example.

During a class, Alex(andra) moves non-stop on a chair and feels restless and bored because his/her situational needs for action and meaningfulness are not being met at. Having seen Alex(andra)'s constant movement, the teacher might feel annoyed because of the need for order and structure, and concerned owing to a need to create an environment supportive of students' learning. Simultaneously, some of the classmates might feel enjoyment because their need for fun is met by Alex(andra)'s movement; they might even intentionally provoke him/her further to fulfill their need for fun as well as affinity with other students taking part in the provocation. By contrast, some classmates might feel annoyed because they have a need for a quiet learning environment, or unsecure because they have a need for certainty that the actions of others do not produce disturbance in classroom.

I argue that this way of conceptualizing everyday classroom interaction is far more constructive than the one deriving from disability discourse (i.e., Alex(andra) has ADHD or manifests symptoms of hyperactivity characteristic of the disorder) or normative discourse (i.e., Alex(andra) and his provokers are ill-behaved and disrespectful), because it provides a more constructive basis for understanding need in a way that allows the design and implementation of efficacious pedagogical and classroom management strategies for all. In this case, addressing the needs for action, meaningfulness, structure, affinity, security and learning could be accomplished by agreeing with the class on terms of movement that enables 
the learning of those in need of action while respecting tranquility required for learning by others.

Let us imagine next that after a careful evaluation process, a multi professional team has decided upon Alex(andra)'s transition from the mainstream to a special classroom. This might well be a successful strategy to fulfill his/her and the remaining peers' needs for learning (as regards academic subjects and skills) promoted by a quiet environment. It might also fulfill Alex(andra)'s need for support and help, and the teacher's needs for respect and competence, as well as dissipate the teacher's need for further support because the student $\mathrm{s} /$ he has labeled as a troublemaker does not question his/her actions during class anymore. If, however, Alex(andra) experiences this transition as stigmatizing or exclusionary, it cannot under any circumstances be considered as fulfilling his/her needs for acceptance, integrity or belonging. It most probably also contradicts the teacher's, principal's and parents' needs for supporting the student's socioemotional wellbeing at school.

Thus, when a student's (special or remedial) educational needs such as learning are at stake, it could be beneficial to recognize and account for those whose other needs are (indirectly or unintentionally) affected as well; such as a student's need for affinity and respect; a teacher's need for control, competence, and respect; and the parents' need for collaboration, support, and trust. It is therefore important to distinguish between institutional (that is, imposed) "needs" and actual individual needs, and focus on those of individuals within a specific academic or social context (see e.g., Van Bergen et al., 2015 for a description of hidden motives). In other words, it is necessary to recognize and validate students', parents', and teachers' basic needs that must be acknowledged and fulfilled, without reciprocal normative condemnation of any of the other parties. Therefore, the question those practicing inclusion ought to ask now becomes: whose and which needs are 
they actually catering to, and by what means and ends? How can environments be fostered that consider and address equally the needs of all stakeholders?

\section{Conclusion: Implementing a change of mindset}

Since medical discourses are deeply rooted in the educational comprehension of variation between an individual's behavior and receiving recognition, the promise of ADHD seems to remain salient and self-sustainable in everyday social practices. Therefore, a diagnostic label per se cannot be considered fundamentally undesirable outright. Yet if the educational and pedagogical understanding of a child with difficulties in meeting the expectations of an operating environment is solely diagnosis driven and medicalized, there remains little room for the critical constructive (re-)evaluation of fundamental educational values, ones that take into account basic human needs. Therefore, one of the challenges for inclusive education is cultivating social change that promotes the growth of all students as self-accepting and self-actualizing social agents.

In this regard, the Finnish basic education system that provides a need-based threetiered framework for support presents a potentially efficacious basis for practice for inclusive education in that, in theory at least, it is premised on home-school collaboration for meeting a student's individual needs regarding both learning (i.e., academic and social skills) and learner (i.e., socioemotional wellbeing) outcomes without overt categorization of "normal" and "other." However, inclusive education is not about directive or material changes. It cannot be achieved only through pedagogical practices, but also must include social and discourse practices that establish an environment in which human diversity and acceptance of others and self are embraced. A potential way to eliminate some of the barriers to inclusive education brought forth in this paper is to pay serious attention to how language is used in explaining and characterizing individual traits, behavior, and performance in everyday 
interaction and how pedagogical means of support are experienced and perceived by the stakeholders in light of the values of inclusive education. Accordingly, in closing I have posed two guiding questions those practicing inclusion ought to ask in order to communicate and live up to the values of inclusive education in everyday interaction and practice:

What are the types of identities made available to those deemed having "special" needs?

Whose and which needs are being catered to and by what means and ends?

In this regard, I further propose two guiding concepts stemming from the tradition of NVC: independency and reciprocity (Rosenberg, 2003). The former refers to skills to recognize and express one's own situational needs and find strategies to fulfill them while still respecting the needs of others, whereas the latter means skills to understand others' situational needs and adjust one's own behavior and practice according to those without ignoring one's own needs. I find these concepts complementary to those of motivational displacement and engrossment introduced by Noddings (1984; 1992, in Danforth \& Naraian, 2015, pp. 76-78), by which she emphasizes putting aside personal motivations and offering oneself to the needs of another in order to foster ethic of caring. This way the responsibility of every individual stakeholder to establish a caring, accepting and responsive inclusive education environment becomes accentuated.

To conclude, the point here has not been to provide pedagogical insights or a moral take on arrangements of inclusive education. Instead, I have provided a moral judgment-free conceptualization of situational educational need that does not reproduce normative (e.g., student is ill-behaved), deficit (e.g., student lacks certain valued abilities) or disability (e.g., student has ADHD) discourses which fortify able-disabled and normal-other dichotomies. I have aimed to create a basis for need rhetoric and practice that goes beyond normative 
expectations and psycho-medical explanations - one that regards the basic needs of all stakeholders (students, teachers, and parents). I have shed light upon the nature of interaction as being the core of various inclusive education strategies, whether they derive from the knowledge domains of psychomedical or special educational understanding, or from basic human understanding. Drawing on Ainscow (2007), I conclude that inclusive education is fundamentally about a change of mindset manifested into practice and shared by home and school. When this happens, discourses currently referred to as inclusive will be referred to as normative. 


\section{References}

Adams, P. (2008). Positioning behaviour: Attention deficit/hyperactivity disorder (ADHD) in the post-welfare educational era. International Journal of Inclusive Education, 12(2), 113-125.

Adams, P. (2010). The politics of educating children “with” ADHD. In L. J. Graham (Ed). (De)Constructing ADHD: Critical guidance for teachers and teacher educators (pp. 77-98). New York: Peter Lang.

Ainscow, M. (2005). Developing inclusive education systems: What are the levers for change? Journal of Educational Change, 6, 109-124.

Ainscow, M. (2007). Taking an inclusive turn. Journal of Research in Special Educational Needs, 7(1), 3-7.

Ainscow, M., Booth, T., \& Dyson, A. (2006). Improving schools, developing inclusion. Abingdon: Routledge.

American Psychiatric Association (2013). Diagnostic and statistical manual of mental disorders: DSM-5. Washington, D.C: American Psychiatric Association.

Armstrong, D., Armstrong, A. C., \& Spandagou, I. (2011). Inclusion: By choice or by chance? International Journal of Inclusive Education, 15(1), 29-39.

Bailey, S. (2014). Exploring ADHD An ethnography of disorder in early childhood. New York : Routledge.

Björn, P. M., Aro, M., Koponen, T., Fuchs, L., \& Fuchs, D. (2016). The many faces of special education within RTI frameworks in the United States and Finland. Learning Disability Quarterly, 39(1), 58-66. 
Brady, G. (2005). ADHD, diagnosis and identity. In C. Newnes \& N. Radcliffe (Eds.), Making and breaking children's lives (pp. 49-59). Ross-on-Wye, England: PCCS Books.

Brunila, K. (2012). From risk to resilience. The therapeutic ethos in youth education. Education Inquiry, 3(3), 451-464.

Danforth, S. \& Naraian, S. (2015). This new field of inclusive education: Beginning a dialogue on conceptual foundations. Intellectual and Developmental Disabilities, 53(1), 70-85.

Deci, E.L., \& Ryan, R.M. (2000). The "what" and "why" of goal pursuits: Human needs and the self determination of behavior. Psychological Inquiry, 11(4), 227-268.

Dyson, A. (1999). Inclusion and inclusions: Theories and discourses in inclusive education. In H. Daniels \& P. Garner (Eds.) Inclusive education. World yearbook of education (pp. 36-53). London: Kogan.

Emerald, E., \& Carpenter, L. (2010). ADHD, mothers, and the politics of school recognition. In L. J. Graham (Ed.), (De)Constructing ADHD: Critical guidance for teachers and teacher educators (pp. 99-118). New York: Peter Lang.

Foucault, M. (1972). The archaeology of knowledge. London: Tavistock/Routledge.

Gabel, S. L. (2009). Introductions: Disability Studies in Education. In S. L. Gabel (Ed.).

Disability studies in education: Readings in Theory and Method (Vol. 3) (pp. 1-20). New York: Peter Lang.

Gee, J.P. (2000-2001). Identity as an analytic lens for research in education. Review of Research in Education, 25, 99-125. 
Glasser, W. (1996). Then and now: the theory of choice. Learning, 25, 20-22.

Glasser, W. (1997). A new look at school failure and school success. The Phi Delta Kappan, $78(8), 596-602$.

Graham, L. J. (2015). Reconceptualising inclusion as participation: Neoliberal buck-passing or strategic by-passing? Discourse: Studies in the Cultural Politics of Education, Advance publication. DOI: 10.1080/01596306.2015.1073021

Graham, L. J., \& Jahnukainen, M. (2011). Wherefore art thou, inclusion? Analysing the development of inclusive education in New South Wales, Finland and Alberta. Journal of Education Policy, 26(2), 263-288.

Graham, L. J., \& Slee, R. (2008.) An illusory interiority: Interrogating the discourse/s of inclusion. Educational Philosophy and Theory, 40(2), 277-293.

Harwood, V. (2006). Diagnosing 'disorderly' children, London, England: Routledge.

Hjörne, E. (2006). Pedagogy in the ADHD classroom: An exploratory study of the Little Group. In G. Lloyd, D. Cohen \& J. Stead (Eds.), Critical new perspectives on attention deficit/hyperactivity disorder (pp. 176-197). Oxon: RoutledgeFalmer.

Hjörne, E., \& Säljö, R. (2014). Analysing and preventing school failure: Exploring the role of multi-professionality in pupil health team meetings. International Journal of Educational Research, 63, 5-14.

Honkasilta, J. (2016). Voices behind and beyond the label: The master narrative of ADHD (de)constructed by diagnosed children and their parents. Doctoral thesis, Jyväskylä Studies in Education, Psychology and Social Research 553. Jyväskylä: Jyväskylä University Printing House. Available at http://urn.fi/URN:ISBN:978-951-39-6636-2 
Honkasilta, J., Vehkakoski, T., \& Vehmas, S. (2015). Power struggle, submission and partnership: Agency constructions of mothers of children with ADHD diagnosis in their narrated school involvement. Scandinavian Journal of Educational Research, 59(6), 674-690.

Honkasilta, J., Vehmas, S., \& Vehkakoski, T. (2016). Self-pathologizing, self-condemning, self-liberating: Youths' accounts of their ADHD-related behavior. Social Science \& Medicine, 150, 248-255.

Honkasilta, J., Vehkakoski, T., \& Vehmas, S. (2016). 'The teacher almost made me cry': Narrative analysis of teachers' reactive classroom management strategies as reported by students diagnosed with ADHD. Teaching and Teacher Education, 55, 100-109.

Itkonen, T., \& Jahnukainen, M. (2007). An analysis of accountability policies in Finland and the United States. International Journal of Disability, Development and Education, $54,5-23$.

Itkonen, T., \& Jahnukainen, M. (2010). Disability or Learning Difficulty? Politicians or Educators? Constructing Special Education in Finland and the United States. Comparative Sociology, 9(2), 182-201.

Jahnukainen, M. (2010). Different children in different countries: ADHD in Canada and Finland. In Graham, L.J. (Ed). (De)Constructing ADHD: Critical guidance for teachers and teacher educators (pp. 63-76). New York: Peter Lang.

Kittay, E.F. (2006). “Thoughts on the desire for normality.” In E. Parens (ed.) Surgically shaping children: Essays on technology, ethics, and the pursuit of normality (pp. 96118). Baltimore, MD: Johns Hopkins University Press. 
Kulinna, P.H. (2007-2008). Teachers' attributions and strategies for student misbehavior. Journal of Classroom Interaction, 42(2), 21-30.

Miles, S., \& Singal, N. (2010). The Education for All and inclusive education debate: Conflict, contradiction or opportunity? International Journal of Inclusive Education, $14(1), 1-15$.

Naraian, S. (2013). Dis/ability, agency, and context: A differential consciousness for doing inclusive education. Curriculum Inquiry, 43(3), 360-387.

Noddings, N. (1984). Caring, a feminine approach to ethics and moral education. Berkeley, CA: University of California Press.

Noddings, N. (1992). The challenge to care in schools: An alternative approach to education. New York, NY: Teachers College Press.

Rinne, R., Järvinen, T., Tikkanen, J., \& Aro, M. (2012). Koulutuspolitiikan muutos ja koulun asema Euroopassa - Kahdeksan maan rehtorien näkemys. Kasvatus, 43(5), 460-475.

Rosenberg, M. B. (2003). Nonviolent communication: A language of life. Encinitas, CA: Puddle Dancer Press. $2^{\text {nd }}$ edition.

Ryan, R.M., \& Deci, E.L. (2000). Self-determination theory and the facilitation of intrinsic motivation, social development, and well-being. American Psychologist, 55, 68-78.

Singh, I. (2004). Doing their jobs: Mothering with Ritalin in a culture of mother-blame. Social Science \& Medicine, 59, 1193-1205.

Slee, R. (2004). Inclusive education: A framework for school reform. In V. Heung \& M. Ainscow (eds). Inclusive Education: A framework for reform, (pp. 29-66). Hong Kong, China: Hong Kong Institute of Education. 
Slee, R. (2013). How do we make inclusive education happen when exclusion is a political predisposition? International Journal of Inclusive Education, 17(8), 895-907.

Tait, G. (2010). Philosophy, behaviour disorders, and the school. Rotterdam; Boston: Sense.

Thomas, G., \& Loxley, A. (2007). Deconstructing special education and constructing inclusion. (2nd ed.). Maidenhead, UK: Open University Press.

Van Bergen, P., Graham, L. J., Sweller, N., \& Dodd, H. F. (2015). The psychology of containment: (Mis) representing emotional and behavioural difficulties in Australian schools. Emotional and Behavioural Difficulties, 2(1), 64-81.

van Dijk, T.A. (1996). Discourse, power, and access. In R.C. Caldas-Coulthard \& M.

Coulthard (Eds.), Text and practices: Reading in critical discourse analysis (pp. 84104). London: Routledge \& Kegan Paul.

Vehmas, S. (2010). Special needs: A philosophical analysis. International Journal of Inclusive Education, 14(1), 87-96.

Vehmas, S. (2015). Inclusion, diagnostics, and diversity: ethical considerations. In R. Traustadóttir, B. Ytterhus, S. T. Egilson \& B. Berg (Edits.) Childhood and disability in the Nordic countries. Being, becoming, belonging (pp. 51-65). Studies in Childhood and Youth. New York: Palgrave Macmillan.

Walton, E. (2015). The language of inclusive education: Exploring speaking, listening, reading and writing. London and New York: Routledge.

World Health Organization (1993). The ICD-10 classification of mental and behavioural disorders. Diagnostic criteria for research. 
http://www.who.int/classifications/icd/en/GRNBOOK.pdf [accessed 9 December 2015] 